Milena Manová

\author{
K NËKTERȲM METODOLOGICKȲM PROBLËMƯM KOMPLEXNİHO VȲZKUUMU \\ CLOVËKA V SSSR
}

Př́rodní i společenské vědy mají společnou obecnou metodologií. Je jí dialektický a historický materialismus. Tato metodologie umožñuje současné vědě úspěšně realizovat komplexní výzkum člověka.

Ke komplexnímu výzkumu osobnosti je třeba, aby se spojili se sociology i vědci jiných vĕdních disciplín, nebot jen ve spolupráci s odborníky z různých oborů je možno realizovat všestranný, integrovaný výzkum. Zkoumání člověka přestává být omezeno na rámec antropologických disciplín, změnilo se ve společný úkol současných věd včetně věd fyzikálně-ma. tematických a technických. Při řešení tohoto úkolu se vytvářejí nové vzájemné vztahy mezi přírodními a společenskými vědami, technikou a ekonomií, medicínou a pedagogikou, vědeckým a uměleckým poznáváním a zobrazováním člověka.

Sovětští vědci jsou si vědomi toho, že formulováním úkolů komplexního zkoumání člověka ve společnosti vstupují do světa neobyčejně složitých a různorodých vztahů a závislostí, které zahrnují a sjednocují historii a prírodu. Komplexní, tj. integrované, celistvé vědecké poznání člověka a společnosti není možné bez obecné teorie vztahů a závislostí, které odrážejí jevy společenského vývoje a rozvoje člověka. Tato teorie je základem metodologie komplexních výzkumů, jejich programování, organizace a aplikovaného projektování. Principiálnî význam takové teorie vztahů a závislostí je určován především tím, že právě v systému určitých vztahů se člověk projevuje jednak jako produkt biologické evoluce a velmi složi- tých systémů seberegulace, jednak jako produkt historického vývoje a jako společenské individuum, jed̉nak jako subjekt poznání, práce a styku, jako osobnost a individualita.

Všechny výzkumy věnované vztahům člověka a společnosti $\mathrm{k}$ různým faktorům světa, v němž žiji, k historicky se vytvořivší civilizaci i současnosti, k vzájemnému působení společenské výroby, kultury, společenského styku, rozdělování a spotřeby $v$ materiální a duchovní sfére společenského života jsou však cenné pouze $\checkmark$ kontextu systémů vztahů mezi všemi jevy společnosti a člověka.

Teorie komplexního zkoumání člověka a společnosti nabývají mimořádného významu tím, že na jejich základě mají být vypracovány funkce ř́zení vztahů a závislostí s určitými aplikovanými cíli.

Potřeba takové ucelené teorie se stále více pocituje v různých oblastech praxe. Ve snaze překonat omezenost, jednostrannost, př́ipađně metafyzičnost úzce speciál ního aplikovaného přístupu vidí sovětští vědci jeden ze znaků současné doby.

Složitost zkoumání "systému osobnosti“, a zvláště jejího vĕdomí spočívá v tom, že osobnost je zároveň objekt - subjekt, pro jehož normální fungování je nutná neustálá přemĕna objektivního v subjektivni, vnějšího ve vnitřní, společenského $v$ individuální a naopak.

Je nutno určit takoyou vlastnost $v$ charakteristice společenského života, ve které by obě tyto stránky existovaly $\mathrm{v}$ reálné dialektické jednotě a která by byla hlavním prvkem při formování osobnosti, 
základním integrujícím faktorem ve vytváření jejího vědomí a sociálně psychologických rysů. Touto vlastností je sociální činnost osobnosti, její aktivní vztah k okolnímu světu, a souhrn objektivních společenských vztahů formujících osobnost se realizuje $\mathrm{v}$ různých formách této činnosti.

Pro pochopení osobnosti jako určitého celku je nutné komplexní zkoumání různých druhů činnosti a sociálních funkcí osobnosti, zkoumání vztahů a vzájemných vlivů mezi různými druhy osobní činnosti. Problém je neobyčejně složitý a pro jeho řešení, jak konstatují sovětští sociologové, není ještě shromážděn dostatečný materiál. Zatím se ještě zkoumaji jednotlivé skupiny vztahů, vzájemné působení jednotlivých stránek životní činnosti osobnosti. Nejvíce se zkoumá vzájemný vztah práce, mravního života a chování osobnosti, úloha pracovní činnosti $\mathrm{v}$ etické i estetické výchově člověka, rodinné vzta. hy atd. Získává se materiál pro komplexní výzkum systému sociální činnosti osobnosti v socialistické společnosti a jejích společenských vztahů. Dosud se však zkoumá hlavně profesionální pracovní činnost různých skupin dělnické třídy, ménĕ prozkoumaná je práce kolchozního rolnictva a inteligence.

Komplexní přistup ke zkoumání osobnosti je velmi důležitý, nebot působení různých faktorů je možno pochopit, jen přihlížíme-li $\mathrm{k}$ jejich vzájemnému ovlivňování a prolínání $\mathrm{s}$ vnitřní specifikou osobnosti.

Problematice člověka jsou vĕnovány velmi četné publikace sovětských sociologů, kteři se zaměřují na zkoumání osobnosti z různých aspektů a na různých úrovních sociologického bádání. V mnohých pracích jsou zobecněny výsledky konkrétních výzkumů osobnosti.

Komplexní výzkum člověka se provádí téměr̆ ve všech sociologických centrech Sovětského svazu, zejména však v Leningradě, který patří k největším a nejvý. znamnějším střediskům sociologického bádání. Intenzívní činnost zde vyvijií Sdru- žení pro studium společnosti a člověka, vědecká organizace, která provádí komplexní výzkumy a zahrnuje řadu laboratoří a vědeckých skupin, které provádèjí konkrétní sociologické výzkumy. Laboratoř sociologických výzkumů je zaměřena na sociální aspekty pracovní činnosti člověka, laboratoř sociální psychologie zkoumá pracovní aktivitu dělníkủ. Přední místo $\mathrm{v}$ celkové práci laboratoře zaujímá metodologie a metodika sociálně psychologického výzkumu. Laborator̆ ekonomických výzkumů se zaměřuje na výzkum změn $\mathrm{v}$ profesionální dělbě a obsahu práce pod vlivem technického pokroku $v$ průmyslu. Na tomto tématu spolupracuje laboratoř $s$ př́śslušnými institucemi v Leningradě. Kromě již zmíněných laboratoří zahrnuje Sdružení laboratoř inženýrské psychologie. Se Sdružením pro studium společnosti a člověka spolupracuji mnozí vědečtí pracovníci a učitelé Leningradské státní university. S jejich pomocí se provádějí výběrová šetření volného času, zkoumá se vliv povolání na všestranný rozvoj osobnosti, koná se sociologický průzkum na téma Etika kolektivní práce aj.

$\mathrm{Na}$ bázi uvedených laboratoří se vytvoril Ústav konkrétnich sociologických výzkumů při Akademii věd SSSR a Ustav komplexních sociálních výzkumů při Leningradské státní universitě, které přispivají ke sjednocování vědeckých kádrů v Leningradě při řešení závažných výzkumných úkolů. Hlavním úkolem je komplexní studium otázek člověka a společnosti v období komunistické výstavby, a to prostředky společenských i přírodních věd. Výzkumný program se zaměřuje na člověka a jeho činnost, plánování rozvoje pracovních kolektivů a na sociální problematiku vysokoškolského vzdělání a výchovy studentů.

Výzkum problému Člověk a jeho pracovní činnost zahrnuje zpracování obecné teorie individuálního vývoje člověka a vědeckých základů diferencovaného chápání různých způsobů praktické práce s lidmi. Tento problém se zkoumá hlavně 
ze dvou aspekti̊. První aspekt předpokládá antropologický a fyziologický výzkum vzájemného působení různých vlastností a charakteristik člověka jako individua. Cílem bádání je zjištění individuálních typických zvláštností lidí a vypracování zásad komplexni diagnostiky osobnosti. $\mathrm{Na}$ základě srovnávací analýzy individuálních typických charakterových a sociálně psychologických zvláštností lidí se zkioumá otázka optimálního sdružování lidí v různých druzích skupinové činnosti. Druhý aspekt tohoto problému předpokládá filosoficko-sociologický, ekonomický a právnický společenskovědní výzkum vzájemných souvislostí sociálních charakteristik člověka jako osobnosti - jako subjektu práce, jako spotřebitele sociálních a ekonomických statků, jako subjektu ekonomických, sociálních, politických a ideologických vztahů atd. Cílem výzkumu je zpracování sociální typologie lidí, což má podstatný význam pro studium životního stylu, potřeb, zájmů a požadavků lidí, jejich motivace a rovněž pro plánování sociálního rozvoje kolektivů, optimálních systémů ideologické výchovy a organizace způsobu života i volného času pracujících.

V komplexním zkoumání problému člověka a jeho pracovní činnosti se vyhranily tři smĕry. Prvním z nich je výzkum psychologické struktury a individuálně typických zvláštností člověka a studium individuálních a věkových změn struktury dospělého člověka. Výzkumný program tohoto směru zahrnuje studium těch zvláštností člověka, jež mají velký význam pro určení úrovně jeho celkového rozvoje, jeho pracovních schopností a jeho nadání.

V rámci zkoumání psychologické struktury a individuálních zvláštností člověka se vytváří nová vědní disciplína - akmeologie - věda o fázích a periodách optimálního vývoje člověka, o rozvíjení jeho fyzických a duchovních schopností. Anini v sovětské, ani ve světové vědě dosud neexistuje objektivní vědecká periodizace fází psycho-fyziologické evoluce dospělé- ho člověka a nejsou určeny horní a dolní prahy jednotlivých obdobi dospělosti. Zpracování tohoto problému má mimořádný význam pro všechny oblasti společenské praxe.

Druhým přistupem k problému člověka a jeho pracovní činnosti je výzkum činnosti operátora $v$ složitých automatizovaných řídících systémech. Ústředním problémem je zde rozdělení funkcí mezi technickým zařízením a operátorem a skupinou operátorů a otázka matematického modelování lidské činnosti v řídících systémech. Studium tohoto problému vedlo k vypracování teorie výzkumných metod a principů projektování velkých systémů, k rozvoji metod studia psychofyziologických charakteristik člověka operátora a ke konkrétním technickým doporučením, pokud jde o zařizení, která jsou součástí velkých systémů a spojují člověka s technickými prostředky systému. Výzkumy činnosti operátora v složitých automatizovaných řídících centrech umožňují vypracovat teoreticky zdůvodněnou optimální organizaci liđské činnosti v automatizovaných průmyslových odvětvích, $\mathrm{v}$ dopravě atd. a zpracovat inženýrskopsychologické principy teorie řízení. Při dalším zkoumání těchto otázek se předpokládá vytvoření nového oboru, který by se mohl označit jako psychologické základy profesiologie, tj. projektování nových druhů lidské činnosti. Hlavním úkolem tohoto vědního oboru je zpracování profesiogramů povolání, která jsou aktuální dnes i $v$ budoucnosti. Tyto profesiogramy mají sloužit jako orientace pro volbu povolání.

Dalším směrem studia problému člověka a jeho pracovní činnosti je téma socializace individua jako společenské funkce, tzn. analýza institucí, které realizují socializaci. V rámci tohoto tématu se provádí teoretický i empirický sociologický výzkum struktury a funkcí sociálních institucí, které začleňují jednotlivce do systému socialistických společenských vztahì. Jednak chtějí badatelé zjistit vlastnosti, které charakterizují sociální pozice 
jako elementy sociální struktury, a zkoumat, do jaké míry zjištěné vlastnosti podmiȟují strukturu a funkce institucí socializace. $\mathrm{Na}$ systém těchto institucí je třeba pohlížet jako na systém uspořádaný podél časové, tj. věkové osy, nebot každá instituace je ve své činnosti orientována na určité věkové zvláštnosti. Zpracování tohoto tématu umožní chápat socializaci jako moment reprodukce společnosti a včlenit jednotlivce do systému socialistických vztahů. Výsledky výzkumu slouží jako vědecký podklad pro zdokonalování činnosti institucí socializace.

Leningradský Ústav komplexních sociálních výzkumů zkoumá také sociální problémy vysokoškolského vzdělání a výchovy studentů. Provádí analýzu různých faktorů, které působí na utváření budoucích specialistů, a typologických zvláštností osobnosti studenta. Smyslem analýzy je vypracování optimálního systému organizace učebního procesu a výchovné práce na vysoké škole.

Vyzkum systému „člověk - sociální skupina - společnost" pokládají i ostatní sociologická badatelská pracovištè i jednotliví badatelé za hlavní problém konkrétní sociologické analýzy v současné době. K splnění tohoto úkolu se zkoumají sociální vztahy ve městě a na venkovĕ, vliv vědeckotechnické revoluce na vývoj kolektivu a jedince, postupné sbližování duševní a fyzické práce, způsoby překonávání rozdílů mezi kulturními potřebami člověka ve městě a na venkově, dále se zkoumají nejefektivnější formy socialistického soutěžení uvnitř kolektivů, motivy pracovní činnosti, sociologické aspekty racionálního využívání pracovních zdrojứ, sociální otázky likvidace málo kvalifikované práce, sociální a sociálně psychologické faktory zvyšování produktivity práce a utváření vyspělé osobnosti, překonávání záporných jevů ve vědomí a jednání lidí. Zkoumá se vnější i vnitřní struktura rodiny, sociální funkce mimopracovní doby a volného času jejích členů, sociální aspekty životního stylu, zajištování každodenních potřeb aj.
Zvláštní pozornost se věnuje takovému komplexnímu výzkumu, při němž se zkoumá nejen práce, její náplň a organizace, nejen hmotné sociální a morální stimuly pracovní činnosti, ale i problémy reprodukce pracovní síly a zajištění všestranného rozvíjení osobnosti, problémy sociál. ních změn, probíhajících jak v práci, tak i $\mathrm{v}$ životním stylu. $\mathrm{V}$ takovém komplexním přístupu vidí sociologové zároveñ možnost ukázat i různé rozpory, které je třeba řešit.

Na zkoumání jedince se zaměřuje také laboratoř sociologických výzkumů i nèkteré katedry filosofické fakulty MSU. Výzkum má na zřeteli zejména zkoumání osobnosti $\mathrm{v}$ podmínkách socialismu, sleduje se vztah osobnosti a kolektivu, zjištují se podmínky každodenního života lidí, důraz se klade na aktivitu člověka. Kyjevská laboratoř sociálních výzkumů na katedře dialektického a historického materialismu Státní kyjevské university T. G. S̆evčenka se věnuje výzkumu způsobu života a rozvoje osobnosti $v$ době budování komunismu. Všímá si vlivu práce na formování komunistického uvědomění i vlivu koleḳtivu na utváření nového člověka, na jeho chování v práci i na způsob života. Jedním z nejserióznějších a zároveň masových výzkumů kyjevské laboratoře bylo studium týdenního časového rozpočtu pracujících Kyjeva ve třech velkých podnicích. Zvláštní pozornost byla věnována průzkumu volného času, který nejen sám o sobě, ale i jeho racionální využití přispivá do značné míry ke kulturnimu a đuševnímu rozvíjení osobnosti.

Téměř všechna sociologická pracoviště se zabývají otázkami člověka a jeho poměru k práci, pracovní morálkou a její specifičností. Zpracování tohoto tématu má různou podobu, od přehledu získaných empirických dat až po filosoficky zaměřená díla.

Člověk je nazírán jako subjekt práce, pomocí níž přetváří nejen přírodu, ale i sebe sama. Práce jako základní prvek struktury člověka vystupuje jako charakteristika osobnosti především svou spole- 
čenskou formou a organizací, v podobě druhů činnosti podminuujících místo člověka $\mathrm{v}$ historickém systému společenské výroby, vztahů vlastnictví a rozdèlování.

Sociální dělba práce mezi lidmi odpovídá postavení člověka $\mathrm{v}$ třídní struktuře určité společnosti. Příslušnost osobnosti k určité třídě vytváří jedno $\mathrm{z}$ jejích základních určeni, s kterým jsou bezprostředně spjaty místo a úloha osobnosti ve společenské organizaci. Osobnost je určovăna a podmiňována konkrétními sociálně třídními vztahy, je jejich vyjádřením. Ve společenské dělbě práce spočívají sociálně ekonomické rozdíly nebo sociální stejnorodost osobností, nebot schopnosti a vlohy jsou produktem vzájemného působení prrírody a společnosti uskutečňované $\mathrm{v}$ pracovní činnosti.

Osobnost se utváří ve společenských vztazích člověka. Základními, výchozími vztahy jsou vztahy výrobní. Sociálně ekonomické podmínky, $v$ jejichž systému probíhá společenský styk lidí, patří bezprostřednĕ $k$ charakteristice osobnosti a jeho společenská forma, v níž se uskutečn̆uje výroba materiálního života lidí, jsou zároveň podmínkami jejich činnosti.

Se změnou charakteru vjrobních sil a způsobu materiální výroby se mění i formy společenského styku. Dějiny představují radu navzájem spojených forem společenského styku a člověk jako osobnost se stává vyjadřovatelem a současníkem určité historické epochy, zaujímá určité místo $\mathrm{v}$ sociální struktuře společnosti.

Velmi podstatnou charakteristikou osobnosti je společenskopolitická činnost, národní příslušnost, člověk jako nositel forem společenského poznání, tj. filosofických, etických, estetických a jiných názorů a duchovních hodnot. Lidská osobnost jako duchovní fenomén je organicky spjata se společností, s existujícími sociálními vztahy, závisí na nich ve všech svých podstatných projevech.

Základem obecné teorie vztahů a závislostí člověka ve společnosti je materialistické pojetí dějin, které vychází z určující role výrobních sil a jimi pod- miňovaných výrobních vztahů. Výrobnî činnost člověka je hlavním projevem jeho podstaty, prostř̀edkem potvrzení člověka jako společenské bytosti.

Společenské a ekonomické vztahy jsou základním prvkem lidské osobnosti. Nemohou mít tedy pravdu ti sociologové, kteří určují osobnost jen podle duchovních vlastností, nebot výrobní sîly lidî činí člověka společenskou bytostí, vznikající na základě výrobních sil, spojují všechny postatné strukturní prvky člověka, tj. jako subjektu práce, poznání a společenského styku na všech úrovních jejich projevu, a vytvářejí tím jednotnou celistvou strukturu člověka, a tak i objektivní základ pro integraci různých vĕd pro zkoumání člověka.

Dřivější poměrně abstraktní přístup sovětských filosofů a sociologủ $\mathrm{k}$ problematice práce člověka a její technické, psychologické a sociální souvislosti byl $\mathrm{v}$ posledních letech vystrúdán snahou o konkrétní sociologickou a sociálnè psychologickou analýzu charakteru práce, pracovnich podminek a pracovnich postojů. I zde mají sociologové na zřeteli, že pracovní činnost působí nejen na změnu prrírody, ale i na změnu člověka a formu jeho společenských vztahů. Sociologové zkoumají mechanismus objektivního vlivu socialistické práce, která se chápe jako svébytná škola života, formující morálku člověka. Práce se chápe jako činnost, osvobozená od jakéhokoli vykořistování a diskriminace, liší se organizací, důsledným plánováním, tvůrčí soutěživostí a uvědomèlou disciplínou od práce $\mathrm{v}$ kapitalistickém zřízení. Zdůraznuje se socialistický charakter práce s jeho typickými rysy svobody, harmonického prolnutí individuálních a společenských zájmů, její nové morální ocenění. Zájem jedince je spojen nejen s vlastní prací, ale i s rủstem produktivity práce celé společnosti. Tyto závěry se opírají o výsledky konkrétních výzkumů a jsou publikovány $\mathrm{v}$ řadě prací sovětských sociologů zabývajících se touto problema- 
tikou. ${ }^{1}$ ) Zkoumaly se nejdůležitější stimuly individuální spokojenosti pracovníků, otázka zachování či zrušení pracovních specializaci $v$ souvislosti $\mathrm{s}$ jejich vlivem na rozvoj lidské osobnosti, ${ }^{2}$ ) vnitřní dichotomičnost práce a pracovních vztahư ${ }^{3}$ ) na podkladě výzkumů se analyzují závislosti mezi technickou tvořivostí a takovými faktory, jako je obsah práce, úroveň vzdělání, kvalifikace, délka práce a věk dělníka, typické rysy osobnosti dělníka, spjaté s obsahem práce, ${ }^{4}$ ) přìčemž se poukazuje na to, že studium další evoluce charakteru a obsahu práce $\mathrm{v}$ souvislosti s rozvojem moderní techniky má mimořádný význam pro určení způsobů uvědomělého formování takových rysů osobnosti, které by podmínily její harmonické rozvíjení. Zkoumá se i sociální podmíněnost emocionálního vztahu k práci jedince a vliv kolektivu na zvyšování zájmu o práci. ${ }^{5}$ ) Ukazuje se, že sociologický výzkum nejen přispivá k překonání zjednodušených představ o automatické projekci sociálně ekonomických podminek ve vědomí člověka a jeho postojích $k$ práci, ale vyústuje v řadu konkrétních sociotechnických návrhů, s kterými se seznamují stranické orgány a v praxi jich využívají. Sociologové si uvědomuj di̊ležitost vztahu pracovní morálky a socialistické organizace práce, výchovy k solidaritě, uvědomělosti a pocitu odpovědnosti za společné dílo.

Výsledky výzkumů postojů člověka

1] Je to například dílo V. G. N ě s t ě r o$v$ a Trud $i$ moral $v$ sovetskom obšcestve, Moskva 1969 a kolektivní dílo pracovníků laboratoře pro sociologický výzkum v Leningradě: V. A. J a d o v, A. G. Zdravom ys lov, V. P. R ožin. Celovek $i$ jego rabota, Moskva 1967.

2) Srv. J. Davydov, Trud i svoboda, Moskva 1969.

3) I. I. C̆ ang li, Vlijanije naučno-techničeskogo progressa na ličnost' rabočego, sborník Sociologija i idēologija, Moskva 1969.

$\left.{ }^{4}\right]^{\prime}, 5$ ) Valentinova, Na umova, sbornikk Sociologija $v$ SSSR, Moskva 1969. k práci v leningradských závodech zpracovali leningradští sociologové ve velmi zajímavých studiích. Sledují v nich začlenění do výrobního procesu, uspokojení z práce, spokojenost $s$ výší mzdy, se vztahy uvnitř kolektivu, s určitým druhem práce, s péčí vedení o pracující, s příležitostí ke zdokonalení zručnosti a s organizací práce. Zjištuje se morálně výchovná funkce pracovního soutěžení, při kterém se mají rozvíjet a upevňovat morální rysy, jež se vytvořily na základě osvobození práce. Upozorňuje se na etickou strânku stírání existujících rozdílủ mezi fyzickou a duševní prací. Práce si všimají kvantitativního hodnocení při výzkumu sociálně psychologických vztahủ kolektivu a osobnosti. ${ }^{6}$ \}

Častým tématem sovětských sociologú je vztah člověka a vědeckotecnické revoluce nebo vztah člověka a techniky. Zdůrazñuje se, že technika neosvobozuje člověka od tělesné ani duševní práce, mění se jen její složení, nenahrazuje mozek člověka, nestaví na místo lidské práce síly přirody, ale mnohokrát zvětšuje schopnost rukou a rozumu člověka. Technický progres radikálně mění strukturu veškerého výrobního procesu, místo a roli člověka $v$ něm. Místo bezprostřední účasti člověka ve výrobním procesu nastupují stále složitější druhy zprostředkované práce.

Sociologové upozorňují, že technická reprodukce pracovních funkcí je jen „počáteční" etapa rozvoje techniky, že její největší přednost není tam, kde povrchně napodobuje člověka, ale tam, kde „prodlužuje“ člověka, kde mu dovoluje hlouběji proniknout do př́rody a ovládnout ji, nebot rozvoj moderní techniky, zvláště moderních elektronických počítacích zařízení, v ohromné míre zesiluje rozumový potenciál lidstva. Kladou si otázku o vnitřních hybných silách vývoje tech-

6) Karpov, Kočetov, ك̌ubkin, sborník Sociologija $v$ SSSR, Moskva 1969. 
niky, jež nelze hledat mimo pracovní proces. ${ }^{7}$ ]

Sovětští sociologové připomínají humanistické zaměření vědeckotechnického pokroku $\mathrm{v}$ socialistických zemích, které se projevuje ve změnách $\mathrm{v}$ práci a osobnosti dělníka, a zdůrazňují, že $\mathrm{v}$ technickoorganizačním aspektu mají tyto změny mnoho společného s procesy probíhajícími v západních zemích, avšak v sociálnim aspektu se podstatně liší. ${ }^{8}$ ] Nĕkteré společné rysy spočívají v tom, že zároveň $s$ technickou vybaveností a zdokonalováním výrobních prostředků, které mají za následek změnu forem práce, přetvářejí se vztahy v systému „C̆lověk-výrobní prostředky - předmět práce“ a rozvíjí se společenská povaha práce. Zvětšuje se diferenciace a integrace druhů činnosti, což vyžaduje jak další specializace pracovníků, tak i jejich všestranný růst a zdokonalování.

Dva základní směry lidské činnosti, výrobní práce a vědecká práce, se spojují v jeden přetvářející proud. Hlubokou podstatou současného technického progresu za socialïsmu je přeměna vědy $\mathrm{v}$ bezprostřední výrobní sílu, která se uskutečňuje jednak materializací vĕdeckých znalostí, jednak tím, že se všichni členové společnosti seznámí s vymoženostmi současné vědy.

Automatizace výroby a humanizace techniky tvoří v socialistické společnosti dvě tránky jediného procesu. Člověk jako

7] J. J. Volkov si všímá historických způsobů spojení člověka a techniky: Jde-li o ruční práci, je člověk hlavním elementem pracovní činnosti, jde o subjektivní typ vazby člověka a techniky, u strojové práce je charakteristickým rysem mechanizace a objektivní typ vazby, při práci s automaty stojí člověk vedle technologického procesu, tento typ charakterizuje kybernetizace a svobodný typ vazby. J. J. V o lk ov, Sistema upravlenija obšcestvom i tip social'noj struktury, sbornik Sociologija i ideologija, Moskva 1969.

$\left.{ }^{8}\right)$ I. I. Č a n g li, Vlijanije naučno-techničeskogo progressa na ličnost rabočego, sborník Sociologija a ideologija. základní výrobní síla společnosti, jako subjekt práce a tvůrce hodnot se stává objektem výzkumu $v$ technických vědách nejen proto, že při projektování i těch nejdokonalejších strojů se musí respektovat kritéria vzájemného působení člověka a stroje. Optimizace práce člověka v systému „člověk - stroj“ se stává nejdůležitějším problémem automatické regulace a technické kybernetiky vůbec. ${ }^{9}$ ]

S možnostmi harmonického rozvíjení lidské osobnosti těsně souvisí otázka vol. ného času a jeho využití. Vyyzkum volného času se provádí na Leningradské universitě, kde se srovnávají údaje o využívání mimopracovní doby ve 20 . letech a v současnosti, ${ }^{10}$ ] zkoumá se struktura časových snímků administrativních pracovníků, korelace mezi počtem dětí a vynakládáním času na zvyšování kulturní a profesionální úrovnĕ,11] zpracovávají se výsledky výzkumu volného času pomocí metod variační techniky. Otázkou volného času se zabývají pracovníci Sibiřského oddělení AV SSSR,12\} zaměřují se na výzkum časového rozpočtu, ${ }^{13}$ \} zkoumají perspek-

${ }^{9}$ ] B. G. An a ̌ jev a V. J. J e $l \mathrm{mejev}$ upozorñuji na antropologizaci technických věd, která souvisí s automatickou regulací strojů a mechanismů. Metodologičeskije osnovy kompleksnogo issledovanija čeloveka, Sociologija i iđaeologija.

10) Kolpakov, Prudenskij, Sociologija v SSSR, Moskva 1965.

11) O si p ov, Frolov, tamtéž.

12) Pracovníci Sibiřského oddělení vydali sborník s názvem Vnerabočeje vremia trud'aščichsja, Novosibirsk 1961, v němž jsou zpracovány materiály z výzkumu mimopracovního, zejména volného času pracujících na Sibiři a Uralu. Podávají klasifikaci struktury časového fondu pracovníka (Pruaenskij], zjištujỉ rozdíl mezi volným časem mužů a žen (Strumilin), využívání volného času pro zvyšování kulturně technické úrovně pracujících.

13] O tom svědčí jejich publikace Meždunarodnoje sravnitel'noje issledovanije bjudžeta vremeni, Novosibirsk 1969.

$Z$ dalších publikací zabývajících se otázkou volného času uvedeme ještě alespoň některé, podle našeho názoru nejreprezentativnější: G. S. P et- 
tivy volného času a sociálně ekonomické problémy volného času za socialismu aj. Poukazují na nutnost vychovávat ke kultuře volného času v socialistické společnosti a na nový, téměř nezkoumaný problém, tj. prognózu a plánování využivání volného času a přechod ke zdokonalování jeho regulace na podkladě bilance.

Další předností sovětské sociologie je cílevědomá snaha o zachycení komplexního charakteru sociálních vztahů, což umožňuje zkoumat společnost $\mathrm{v}$ mnohotvárnosti jejích specifických stránek. Analyzuje se pojem sociální skupina a pozornost se zaměřuje na osobnost a její postavení ve společnosti.

Sociální problémy rozvoje duchovniho života, které zkoumá Institut filosofie AV SSSR, filosofická fakulta MSU, Leningradská státní universita, Uralská fỉliálka AV SSSR, Sverdlovská universita, mají na zřeteli utváření rozvité, sociálnĕ aktivní, tvůrčí osobnosti, zkoumáni prostředků a metod boje s přežitky ve vědomí lidí, překonávání rozporủ růstu, aktivnosti různých prostředků a forem ideologické práce, sociálně psychologické aspekty vývoje prostředků masové komunikace, zkoumání vzájemných vztahů vzdělání, morálky, estetického rozvoje a tělesné kultury při formování nového člověka, způsobů zvyšování společenskopolitické aktivity pracujících.

Osobnost se nezkoumá nikdy izolovanĕ, ale vždy ve vztahu ke kolektivu, ke společnosti. Podle G. M. Andrejevové musí být obraz člověka $\mathrm{v}$ sociologickém $v \hat{y}$ zkumu vždy zároven̆ obrazem společnos-

ros ja n, Vnerabočeje vremja trudaščichsja SSSR, Moskva 1965; sborník Narodnoje chozjajstvo SSSR v 1965 godu, statistický sborník, Moskva 1966; B. A. Grušin, Svobodnoje vremja, Moskva 1968; sborník Sopostavlenije urovněj ekonomičeskogo razvitija socialističeskich stran, Ekonomika, Moskva $1965 ; \mathrm{V}$. D. P a t r u š e v, Svobodnoje vremja $i$ naučno-techničeskij progress, Moskva 1969. Ze starších bychom uvedli ještě alespoň S tru milinovu práci Problemy ekonomiki truda, Moskva 1924 ti. ${ }^{14}$ \} Výběr hypotéz je beze zbytku určován obecnou teorií otázky. Andrejevová má na zřeteli dva hlavní komplexy otázek: analýzu postavení člověka v současné společnosti a výběr metod a prostředků pro zkoumání tohoto postavení; rozvíjení sociologických výzkumů a jejich spojení s teorií pokládá za jedině plodný způsob výzkumu.

Někteří sociologové se zamýšlejí nad postavením individua $\mathrm{v}$ konzumni kapitalistické společnosti a v socialistické společnosti, ${ }^{15}$ \} vyjadřují nesouhlas s tĕmi sociology, kteři určují osobnost, aniž uznávají společenské, především ekonomické vztahy jako základní prvek lidské osobnosti, zkoumají význam sociálního prostředí, všímají si struktury skupinových vztahů a jejich konkrétního sociálně psychologického výzkumu. ${ }^{16}$ ) Pozorují člověka $v$ systému politických vztahů současného světa, ${ }^{17}$ ] zabývají se problémem postavení člověka a jeho funkcí v pracovním společenství. ${ }^{18}$ ) Zaznamenávají určité změny, které prodělává jak pracovní kolektiv, tak i osobnost, a všímají si, jakými změnami prošel pracovní kolektiv i osobnost za léta sovětské vlády, uvažují o vztazích mezi společností, kolektivem a individuem a zvláště vyzvedávají zásadu, že to, co je výhodné pro individuum, musí být výhodné i pro kolektiv, a tudíz i pro společnost jako celek.

Zaměřují pozornost na člověka a jeho sociální aktivitu, která směr̆ováním ke

14) G. M. Andrejeva, Obraz čeloveka $i$ vybor gipotez $v$ socialnom issledovanii, Sociologija i ideologija, Moskva 1969, str. 196.

15) I. F. B a l a k i n a, Individ i massovoje potreblenije $v$ kapitalističeskom obs. cestve, Moskva 1965.

${ }^{16}$ ) I. N. Bujeva, M. J. Kovalzon, Socialnaja sreda $i$ formirovanije ličnosti, Sociologija i ideologija, Moskva 1969.

17) M. B. M it in, Celovek $v$ sisteme političeskich otnošenij souremennogo mi$r a$, cit. sborník.

10) N. I. L a p i n, Čelovek $v$ trudovom $\mathrm{kol}$ lektive, tamtéž. 
knomunismu nejen vzrůstá, ale zároveñ se mění i struktura sociální činnosti člověka, jejî zaměření, stimuly a sociální důsledky. ${ }^{19}$ ) Zaznamenávají rozdílný vztah osobnosti k práci za kapitalismu a za socialismu.

Sovětští sociologové zároveň usilují ve svých studiích osobnosti o to, aby ukázali přednosti marxistického hlediska a omezenost pozitivistického, behavioristického a strukturnë funkcionálního přistu$\mathrm{pu} \mathrm{k}$ problému člověka. Jsou si vědomi toho, že je třeba ještě důkladněji a všestranněji zkoumat problematiku člověka jak v plánu metodologickém, tak i v substancionálním. Jsou si vědomi nutnosti integrace vědeckých znalostí o člověku a celé řady praktických opatření.

Ukazují, že vztahy v různorodých kolektivech se utvářejí na různých záklađech a že jeden a tentýž člověk se chová různě podle toho, $\mathrm{v}$ jakém kolektivu v daném okamžiku působí a jakou roli v nĕm hraje. ${ }^{20}$ ) Mnoho pozornosti věnují sociologové otázce rolí, které člověk plní ve společnosti. Na tuto problematiku se zaměřil v několika pracích I. S. Kon. ${ }^{21}$ ] Poukazuje na některé nesprávnosti teorie rolí u západních sociologů, v zásadě však je přesvědčen o užitečnosti a použitelnosti této teorie i pro socialistickou společnost.

Musíme však nutně konstatovat, že i když je problematika osobnosti $\mathrm{v}$ současné době středem pozornosti sovětských společenských věd, zůstává v ní stále ještě mnoho nevyřešených otázek. Právě na takové otázky se zaměřil podle našeho názoru I. S. Kon ve své podnětné knize Sociologie osobnosti, kde osvětluje některé aspekty postavení osobnosti ve

19) L. V. S o c h a ň, Social'naja aktivnost' ličnosti kak faktor razvitija čeloveka, tamtéž.

20) Selivanov, Sociologija $v$ SSSR, Moskva 1965, str. 466.

2I] I. S. K o n, Ličnost' kak subjekt obščestvennych otnošenij, Moskva 1966; Licnost' $i$ jego socialnyje roli, Sociologija a ideologija, cit. sborník; Sociologija ličnosti, Moskva 1970. společnosti $z$ hlediska marxistické sociologie, znaží se o upřesnění pojmů, kterých věda používá $k$ popisu chovámí osobnosti, její interakce s druhými jedinci a společností jako celku, ukazuje, že osobnost není pouze produktem, ale i aktivnim. činitelem společenských vztahů-a objasňuje řadu v sovětské sociologii dosud nezpracovaných nebo sporných otázek teorie osobnosti, jako jsou stadia a mechanismy utváření osobnosti a jejího postupného sebeuvědomování $\mathrm{v}$ procesu ontogeneze, vliv společenské dělby práce na osobnost, problém odcizen a všestran-

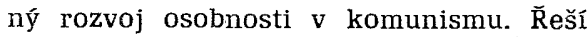
otázku osobnosti jako produktu společenských vztahů, sociálních rolí, sleduje proces přetváření člověka $\mathrm{v}$ osobnost a místo osobnosti $\mathrm{v}$ dějinách společnosti a všestranný rozvoj osobnosti v komunistické společnosti. Zvláště bychom vyzvedli, že i když má práce vysokou teoretickou úroveň, nezůstává $\mathrm{v}$ abstraktní rovině, opírá se na mnohých místech o výsledky konkrétních sociálních výzkumů, např́lklad $\mathrm{v}$ kapitole Osobnost a kultura, u otázky volného času, vztahu k práci, k povolání aj., což je podle našeho názoru typické i pro jiné teoretické práce sociologického charakteru.

Další sociologické práce jsou zaměřeny na výchovu člověka. Kolektiv je označován jako usměrňující faktor pro chování osobnosti. Různorodé vztahy $v$ něm přispívají $\mathrm{k}$ harmonickému rozvíjení osobnosti, zároveň však cílevědomá výchova není možná bez sladěnosti, shod mnohých kolektivi̊ ve svých požadavcích na chování člověka. ${ }^{22}$ ]

Především však vystupuje ve všech pracích sovětských sociologů člověk jako aktivní tvůrce, jehož rozhodnutí mají $\mathrm{v}$ souvislosti $\mathrm{s}$ jeho úlohou ve společ-

22j V. A. Dzjuba I ova, o poñatii proizvodstvennogo kollektiva, Voprosy filosofii i psichologii, Leningrad 1965. Podobně i další publikace: J. B. V a rñak ova, Razvitije ličnosti raboče. go, Moskva 1963; A. I. A f a n a s jeva, A. A. N urrula jev, Kollektiv ličnost', Moskva 1965. 
nosti, s mírou odpovědnosti, kterou na něho společnošt vložila, ohromný význam pro ostatní iidi. Mimořádného významu nabývá tudíž zkoumání působení různých systémů sociálních vztahů na obraz života, chování, pracovní i mimopracovní činnosti člověka. K řízení činnosti jednotlivých individuí a skupin je nutno znát nejen obecnou determinantu, ale i všechny podmiňujici faktory, mechanismy jejich vzájemného působení i funkční spojení těchto mechanismů se sociálním organismem jako celkem.

$\mathrm{Z}$ nastíněné problematiky zřetelně vysvítá, jaká neomezená péče je v Sovět- ském svazu věnováma výzkumu potřeb společenských skupin a jednotlivců a že tento výzkum je třeba provádĕt na vědeckém základě, aby uspokojování přirozených požadavků pracujícího človĕka v socialistické společnosti bylo viděno $\mathrm{v}$ nejpodstatnějšich rysech. K splněni těchto požadavků přispívá nemalou měrou sociologie a sociologický výzkum ve spojení $s$ jinými vědami, zejména sociální psychologií a psychologií osobnosti. Sociologie se zde však ukazuje jako nezbytný článek $\mathrm{v}$ řetězu získávání vědeckých poznatků, na jejichž základě je teprve možno formovat a uspokojovat socialistického člověka.

\section{Alvin W. Gouldner, The Coming Crisis of Western Sociology}

Basic Books, Inc. Publishers, New York, Londo n 1970, str. 528

Kniha amerického sociologa A. W. Gouldnera, profesora sociální teorie na Washington University, St. Louis, byla již dlouho předtím, než vyšla, reklamována jako nejvýznačnější kniha desetiletí o sociologii. V určitém smyslu reklamní hesla tentokrát nepřeháněla a skutečnè je možné tuto práci zařadit $\mathrm{k}$ nejvýznačnějším pracím o sociologii, jež vznikly na půdĕ americké sociologie. A. Gouldner podává široký a také hluboký kritický obraz stavu soudobé americké sociologie i analýzu přičin oné krize, $v$ níž se americká sociologie již nacházî. Kritické ostří Gouldnerových analýz je zvláště zaměřeno na kritiku americké strukturálně funkcionalistické koncepce sociologie, jak ji především reprezentuje T. Parsons.

A. Gouldner považuje svou práci za část širšího pracovního plánu, jehož pruním výsledkem byla práce o Platónovi. Zamýšlené další práce, jež mají následovat, mají stejný cíl jako práce, jež již vyšly - přispět $\mathrm{k}$ historicky informované sociologii sociální teorie. Na jiném místě své práce Gouldner mluvî o nuthosti vypracovat sociologii sociologie, jakési kritické a sebekritické reflexe o smyslu, postavení, úkolech a mož- nostech sociologie a sociologa $\mathrm{v}$ moderní společnosti. Kniha A. Gouldnera není tedy prací, jež je výhradně věnována problémům metod či metodologie, kritické úvahy o problematice metod i otázky obecné metodologie jsou však významnon a důležitou částí celé práce. Poněvadž Gouldnerova práce zaslouži pro svůj zásad ní a hluboký kritický pohled všestranné zhodnocení, není možné postihnout její přinos a podnětnost $v$ krátké recenzi. Proto se soustředíme jen na ty části práce, které se přímo a výslovně dotýkají otázek obecné metodologie nebo vlastnich výzkumných metod a technik, jež použivá soudobá americká sociologie. Výrazným rysem Gouldnerova přistupu k otázkám metody je všestranný a celistvý pohled na otázky metody, které nejsou chápány ani jako čistý problém obecné metody, jež je produktem logických úvah autonomní vědy, nezávislé na charakteru a podstatě studovaného objektu, ani jako záležitost čistě věcných a instrumentálních metod a technik sociologického výzkumu, které jsou ideologicky, politicky a morálně lhostejné či neutrální. Můžeme dokonce s určitým podivem konstatovat, že Gouldner nesdílí, a to naprosto vědomě, předsud- 